\title{
Conflict between Traditional and Modern Muslim Practices
}

\author{
Dávid Somfai Kara \\ Institute of Ethnology, RCH, Hungarian Academy of Sciences, Budapest
}

\begin{abstract}
One of the modernization conflicts of Kyrgyz and Kazak society is discussed in this article. It is the conflict between traditional religious activities, post-Soviet Islamic revival and fundamentalism. The Islamization process in Central Asia started during the Mongol Era $\left(13^{\text {th }}-16^{\text {th }}\right.$ centuries). The nomadic population was also influenced by Sufi tradition in Central Asia that goes back to the $12^{\text {th }}$ century, but it was labeled as shamanism during Soviet times. After the democratic changes and the declaration of religious freedom, some elements of this 1000-year-old tradition have been revived or revitalized. But the so-called official Islam, sponsored by Arabic states, has turned against the popular version of Islam by using the Soviet label of shamanic tradition. In reality, people practicing these traditions are devoted Muslims, they consider them to be pure Islamic traditions. But nationalist or ethnic religious movements, as well as urban esoteric practices, also incorporate elements of this tradition to legitimize their activities. This creates a very complex situation and a growing hostility between fundamentalist and traditional religious groups. Keywords: popular Islam, vernacular Islam, Sufism, fundamentalism, shamanism, nationalism, neo-paganism
\end{abstract}

The spread of Muslim Fundamentalism in Central Asia is a well-known fact. Many aspects of this have been studied in the western media: its political and security consequences, its conflicts with the secular states, and its influence on post-Soviet society. In this study, I would like to examine a less known phenomenon: post-Soviet Islamization and its conflicts with traditional (popular) Muslim practices. Post-Soviet Islamization attacks practices, traditions that are common among the societies of rural areas and village (aul) communities. The traditional practices and ideas have not really changed during the seventy-year Soviet rule (1920-1991), but twenty years after the end of anti-religious ideology, fundamentalist movements that define themselves as "official" Islam once again attack these traditions, although "popular" Islam has a legacy of 1000 years in Central Asia. ${ }^{1}$

\footnotetext{
${ }^{1}$ Islam first spread to Central Asia in the $8^{\text {th }}$ century, after the battle in the Talas Valley (751), when the troops of the Abbasid Arab Caliphate defeated the Chinese Tang Dynasty. This battle led to the Islamization of the flourishing Soghd culture and the dominance of Farsi (Persian) language among
} 


\section{SOVIET TIMES}

During Soviet times, religious life changed dramatically in Central Asia. Popular religious traditions were prosecuted along with the official Islam. Soviet ethnology tried to prove that popular Islam originated from the remnants of "shamanic" (pre-Islamic) beliefs (BAYALIEVA 1972:3-10; BASILOV 1992:10).

Some Western anthropologists try to avoid the terms of "shaman" and "shamanism" regarding Central Asian Muslims, but the term "healer" suggested by them (BeLLérHANN 2004; KeHL-BODROGI 2006) is similarly inappropriate. The bakši-type ${ }^{2}$ specialists do not limit themselves to healing. Their major task is to communicate with spirits (Divaev 1899:310) and to find out the will of God. During Soviet times younger generations turned away from religion due to communist ideology. Only small circles of rural societies practiced religious traditions secretly. After the collapse of the Soviet regime, both official Islam and folk traditions started to revive.

\section{POST-SOVIET TIMES}

The healthcare system founded during Soviet times was in disarray or became really expensive lately in many parts of the region. There are more and more communities, especially in rural areas, seeking the help of the spirits to heal and to mediate their wishes to Allah. But this is not some kind of neo-pagan or neo-shamanic movement. This is the revival of the Muslim folk traditions based on a 1000-year-old Muslim legacy in Central Asia, and it has very few pre-Islamic elements. After the collapse of the Soviet system, local Muslim organizations received assistance from abroad, mainly from Arabia, and many mollas or higher clerics (imam and mufti) were educated in Arabic medrese schools. Of course, Arabic religious ideology rejects popular Muslim traditions, which was strengthened by Soviet scholarship that interpreted Muslim folk traditions as "shamanism in the disguise of Islam" (BAYALIEvA 1972:10). New religious leaders often came from the ranks of former communists, who after the downfall of their party tried to gain status in society through religion. These people, who were educated according to the exclusive ideology of communism, have no tolerance whatsoever towards reviving Muslim folk traditions.

the local Iranian people (Tajiks). Later Tajiks themselves founded a Muslim state ruled by the Samanid dynasty (819-999). Due to Samanid influence, Karluk Turks were also converted to Islam in 934. Their leader Satuk Bughra-khan (Golden 1992:214) founded the Karakhanid dynasty that conquered the Samanid state, too. Meanwhile, Oghuz Turkic tribes of the Syr-darya migrated to the territory of Khorazm and one of their leaders, Salchuk beg (GoldEN 1992:218) also converted to Islam in 985. Salchukid Oghuz (Turkmens) later also occupied Iran, Azerbaijan and Anatolia, and a great number of Turkmen tribes migrated to these regions.

${ }^{2}$ For the Kazak and Kyrgyz terms I used the philological transliteration of Turkology while for names I used the popular English transliteration. 


\section{FIELDWORK EXPERIENCE}

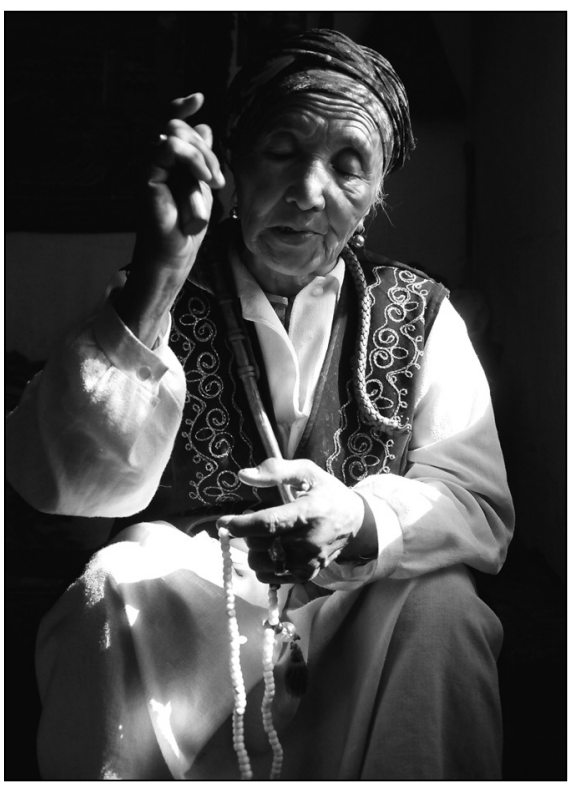

Figure 1. Chachikei during a healing session in her house (dem saluu) using her magic tools (knife, rosary and whip), Talas Valley, Kyrgyzstan, 2008. (Photo by Dávid Somfai Kara)
I have been collecting folklore among the $\mathrm{Kazak}^{3}$ and Kyrgyz since 1994. I was an MA student of Turkic philology when I started fieldwork, but my research focus soon became the folklore of Central Asian Turks in the post-Soviet era. I have spent more than two years in Kazakhstan and Kyrgyzstan mastering the languages so that I could become fluent to collect folklore without an interpreter. This enabled me to travel freely and live in various rural communities (nomadic and settled) in the former Soviet republics of Kazakhstan, Kyrgyzstan, Uzbekistan and Eastern Turkestan (Xinjiang, China). I mainly collected oral literature (folk songs and epic tradition) and only a few examples of religious folklore (together with József Torma and László Kunkovács) (SomfaI 2004; 2005; 2006b, 2008b). But I have soon recognized the strong link between oral literature, religious folklore and spirituality. After 2003, I started working at the Institute of Ethnography, where I concentrated on religious and spiritual folklore (including the so-called cultural phenomenon of shamanism). Having defended my $\mathrm{PhD}$ thesis in Altaic linguistics entitled Vocabulary of

Religious Folklore in 2006 (SomFa 2006a), I decided to commence a long-term fieldwork among the Kazak and Kyrgyz, where I had the chance to live with local spiritual leaders and religious specialists. This enabled me to witness many aspects of their lives, their social network in the course of their religious and social activities. I participated in rituals, healing, and sometimes heard conversations within their circles and family that would have been impossible through short visits and interviews. My fieldwork in Kyrgyzstan was sponsored by the Hungarian State's Eötvös Scholarship (Budapest), while my fieldwork in Kazakhstan was sponsored by the International Turkic Academy (Astana).

Between 2008 and 2009, I spent several weeks in a small Kyrgyz village in the Talas Valley, and I had the opportunity to gain insight into the lives of several religious specialists. Talas Valley is a famous pilgrimage destination. An ancient Karakhanid tomb is situated there that local people believe to be the tomb of Manas, their legendary epic hero. They often come here to pray to God and venerate the spirit of Manas. In Kyrgyzstan, where there are few holy places and tombs, the nomads also venerate features of nature (springs, lonely trees, rocks) as mazars (holy tombs). They believe that spirits of saints can possess them (Kyrgyz eesi bar, Kazak kiyesi bar, "it has a possessor/master", see also SomFAI 2008a).

\footnotetext{
${ }^{3}$ I use the proper form Kazak (Qazaq) instead of the Russian form Kazakh, which was introduced during the Soviet times to differentiate it from the Cossack whose Russian name is identical.
} 


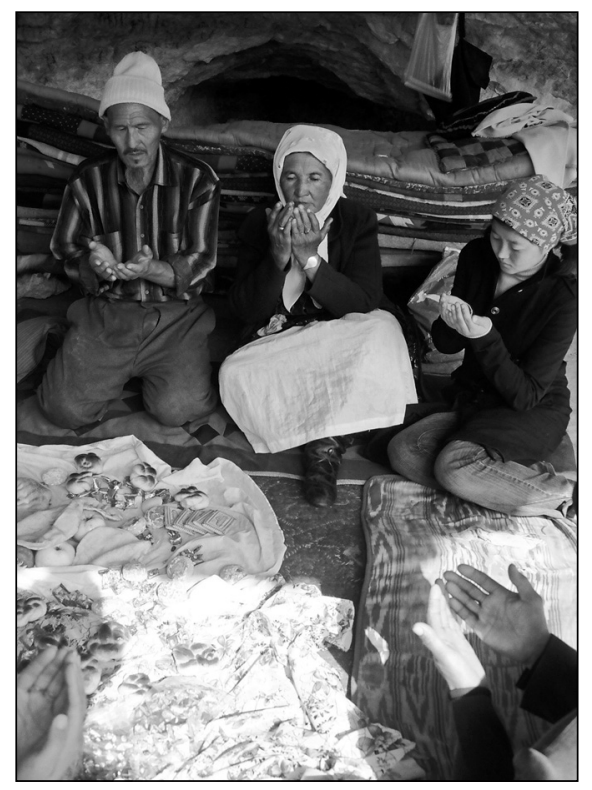

Figure 2. Chachikei and the keeper (shaikh) of Nyldy-ata mazar perform a Muslim prayer (dua) inside a cave of the sacred sight (mazar), Talas Valley, Kyrgyzstan, 2008. (Photo by Dávid Somfai Kara)

One of my most important informants was 70-year-old Chachikei who was considered a clairvoyant (Kyrgyz közü-ačik or körögöč, Kazak köripker) in her village. She received her ayan (vision) in her youth, just like other religious specialists. A spirit appeared to her by a tall plane tree (cinar-terek) in the flood-basin of the Talas River. Chachikei started visiting sacred places of the region in Soviet times, where they secretly held rituals too (Kyrgyz zikir or jar invocations with $\check{s} a m-j a g \bar{u}$, "lighting candles"). In those times, local police harassed them if they wanted to spend the night at sacred places to keep vigil and pray. Nowadays, Chachikei can freely conduct healing rituals (dem salū) using knives, whips and axes to chase away the evil forces (jin-peri). She is a very religious person: she performs the Muslim prayer (namaz) five times a day, and her dream is to do the holy pilgrimage (Arabic hajj) to Mecca. But the local Muslim teacher (molla), who was a member of the communist party during Soviet times, openly criticized her in the community for her rituals and healing activities. I also witnessed that during the Qurban Muslim holiday ${ }^{4}$ he spoke out in public against Chachikei's religious activity. But the prestige of Chachikei was stronger because her rituals and healings were well accepted by the local community, while the molla was known as a former communist. I also visited sacred places (mazar) with Chachikei, where besides spirit-invoking rituals she performed Muslim prayers. She always emphasized that these rituals are part of "being Muslim" (musulmancilik). The spirits and sacred places are only the manifestation of God's almighty power (Arabic qudrat), and they are mediators towards Allah. In her activity, religious identity plays the most important part.

Other religious specialists in the region do not emphasize the Muslim character of their rituals and often put the spirit of Manas, the epic hero in the center. This brings an ethnic element to religious rituals since Manas is an important part of their ethnic identity. Near the so-called tomb of Manas, they built a sacrificial place (tülöö-kana) where people perform sacrifices and rituals to venerate the spirit of Manas and other ancestors. These religious movements in the post-Soviet era, which emphasize the ethnic elements in their religious traditions, introduced the notion of kïrgïzčilik, "being Kyrgyz" (AYTPAEVA 2007:507), replacing the former term musulmančilik. Religious identity is being replaced by ethnic identity. The problem is that religious traditions are more or less common to all the Turkic ethnic groups (Kazak, Karakalpak, Uzbek, Uyghur, etc.), and ethnic peculiarities are scarce.

\footnotetext{
${ }^{4}$ In the Qurban "sacrifice" holiday, the Muslims commemorate that the prophet Ibrahim (Abraham) performed his first sacrifice to Allah.
} 


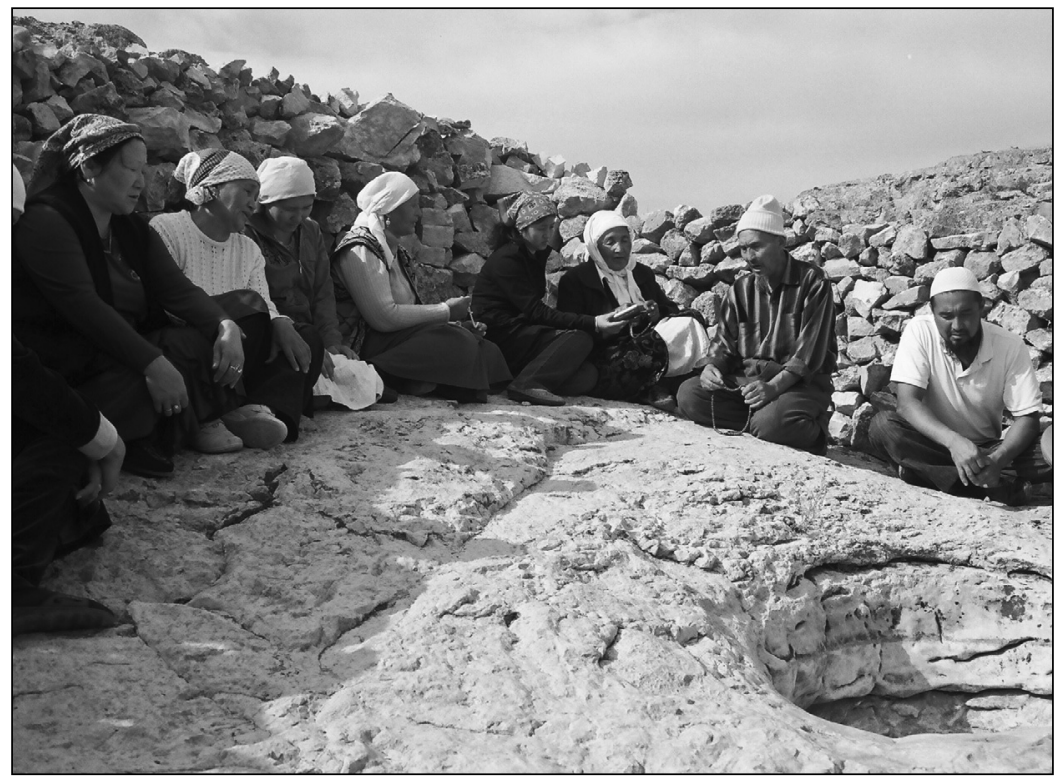

Figure 3. Chachikei and the keeper (shaikh) of Nyldy-ata mazar perform a spirit invoking chant (zikr)near the Köz-bulak (Eye Spring) sacred sight accompanied by local pilgrims, Nyldy-ata, Talas Valley, Kyrgyzstan, 2008. (Photo by Dávid Somfai Kara)

The representatives of official Islam consider these rituals pagan (kaapir) because sacrifice (qurban) can only be performed to God and prayers should be addressed directly to Allah. Many religious specialists defend themselves that they only worship God, and spirits are chosen by Allah to be his mediators towards human beings. Spirit-invoking rituals (zikir and jar $)^{5}$ originate from Sufi tradition and have a 1000-year-old legacy in Central Asia. ${ }^{6}$ These traditions were practiced mostly by Sufi derwishes or wandering dewanas (Kyrgyz dubana/dumana, Kazak diywana). In the Talas Valley I met such a dewana who used to travel from village to village with his magic staff (asa-tayak or asamusa) to chase away evil powers (jin-peri). He distanced himself from spirit-invoking rituals and emphasized that he was the descendent of an old derwish family. Traditions are getting mixed nowadays, so more and more bakšï and bübü (female religious specialists, from Persian bibi) start using magic staffs during their rituals. Chachikei was also taking part actively in the local religious events at the beginning of the revival,

\footnotetext{
${ }^{5}$ The word jar comes from the Arabic expression dhikr bi-l-jahr, meaning "loud dhikr."

${ }^{6}$ Along the Syr-darya: Otrar, Taraz, Aspijab (Sairam) and Yasi became important cultural and religious centers between the 10th-12th centuries. Near Otrar lived the legendary Arslan baba Sufi sheikh who initiated Khoja Ahmad (1093-1166) to the mystic knowledge of Sufism. Later Khoja Ahmad (Hazrat-i Turkistan) moved to the town of Yasi (MÉLIKofF 1987:83) and founded his Sufi order (tariqa-i yasawiya). Due to the Mongol invasion ( $13^{\text {th }}$ century), these towns of the Silk Road were ruined. In the $14^{\text {th }}$ century nomadic Turkic and Turkicized Mongolic tribes became Muslims after the legendary Baba Tülkes awliya had converted Özbek khan (1313-1341) to Islam (DeWeESE 1994:323). Khoja Ahmad's tomb in Yasi became a famous place of pilgrimage (ziyarat), and at the end of $14^{\text {th }}$ century Temür Amir (1370-1405) ordered the construction of the Hazrat-i-Turkistan mosque.
} 
but soon conflicts developed between the different religious specialists. We could call it a fight for prestige. For this reason specialists often accuse each other of possessing black magic and witchcraft that they use to curse people (ters duba), and of having connections with evil forces (jin-šaytan). The "black" and "white" bakšï-bübü categories have been invented to exclude each other from certain communities. Chachikei also accuses the people who conduct rituals at the tülöo-kana of using black magic, and during my visit she did not want to take part in their rituals. One of the reasons behind this, of course, is the ongoing battle between representatives of the official Islam and the folk religious specialists. Many people, especially members of older generations, do not want to have conflict with Muslim clerics, since they are also faithful believers. They choose to exclude themselves from some communities so that they are not accused of paganism. Instead, they accuse those circles of using black magic, although specialists with religious or ethnic identity practice very similar rituals. The traditional bakši-bübü term is also becoming pejorative for some people, as they believe it is equal to a shaman or pagan priest. A religious specialist form Manjili-Ata by the Ysyk-Köl would rather call herself "soul-healer" (ruh-tabïp), a term that was invented recently. I have experienced the same behavior among other specialists; condemnation of the representatives of "official" Islam causes them to reject traditional categories.

Between 2012 and 2013, I also spent several weeks in Southern Kazakhstan along the Syr-darya. It is a sacred river often mentioned in the songs of Kazak and Kyrgyz bakši (SOMFAI 2007:58) because all the major pilgrimage sites are situated in this area (Türkistan, ${ }^{7}$ Sayram, Otral, Taraz, etc.).

I lived with the epic storyteller Bolatbek in the town of Ken-taw $(37 \mathrm{~km}$ north of the famous town of Türkistan). He turned out to be a spiritual leader not only in the Türkistan region but also in his native Kazaly district (Kyzyl-Orda) between the Syrdarya and Aral Lake (Aral Kara-kum Desert). I recorded his life history and how he became an epic storyteller in an interview. Although he came from a nomadic family of the desert, he started working at the school in the mining and industrial town of Ken-taw. During Soviet times, Kazaks were also introduced to vodka drinking by the communist officials. When Bolatbek got sick from drinking vodka, he attended the ritual of an ethnic Uzbek spiritual leader from the city of Türkistan (Kazakhstan) who diagnosed a spiritual disease (caused by the so-called arwah spirits). When his eyes were opened up to the spiritual world, his spirits first ordered him to become an epic storyteller (arkali jïraw). ${ }^{8}$ Since epic storytelling became almost extinct in Kazakhstan during the Soviet times, Bolatbek started traveling to remote nomadic villages and nomadic camps (awï) around the Aral Lake (Karakalpak Republic of Uzbekistan) ${ }^{9}$ to people who still appreciated his repertoire of epic singing. Sometimes he performed these songs for several days accompanied by the two-stringed dombra instrument. Interestingly, the Kazaks do not have an epic story that is considered the national or ethnic saga of the Kazaks, like the

\footnotetext{
${ }^{7}$ Türkistan is the official name of the former town Yasi along the Syr-darya River in Kazakhstan, named after Ahmad Yasawi who is also known as Hazrat-i Turkistān.

${ }^{8}$ The word arqali means "with backing [of the spirits]," which indicates that he is initiated and assisted by spirits to be able to perform long epic stories.

${ }^{9}$ The Karakalpak Republic is an autonomous region of Uzbekistan inhabited by ethnic Kazaks and Karakalpaks closely related to them.
} 

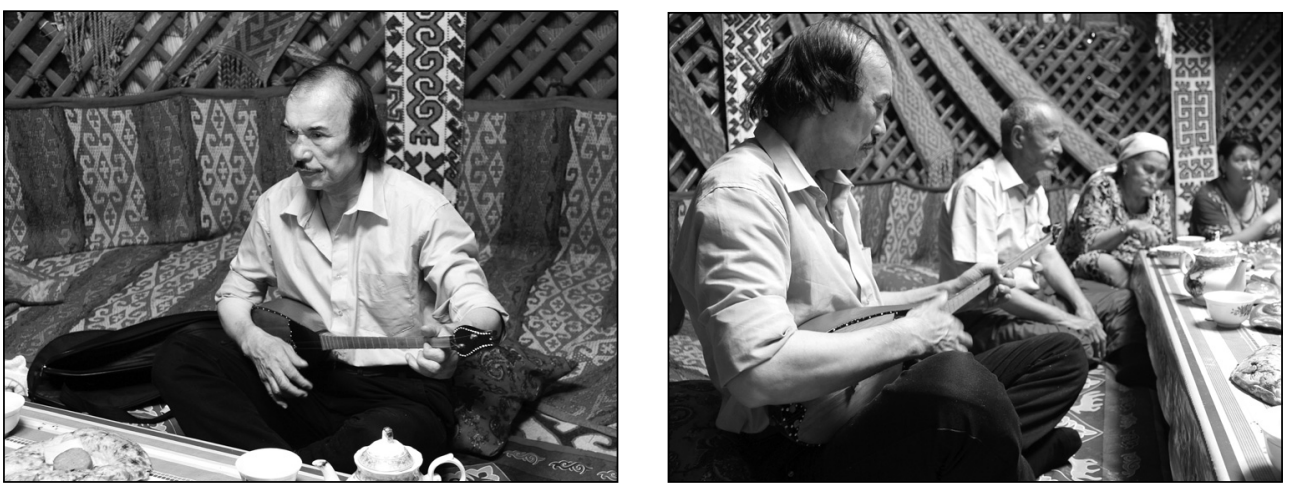

Figure 4-5. Bolatbek epic story-teller (jïraw) is performing an epic song from the Nogai epic cycle of Forty Heroes of Crimea accompanied by his dombra instrument in the felt-house by the table, Aral Karakum, Kazakhstan, 2013. (Photo by Dávid Somfai Kara)

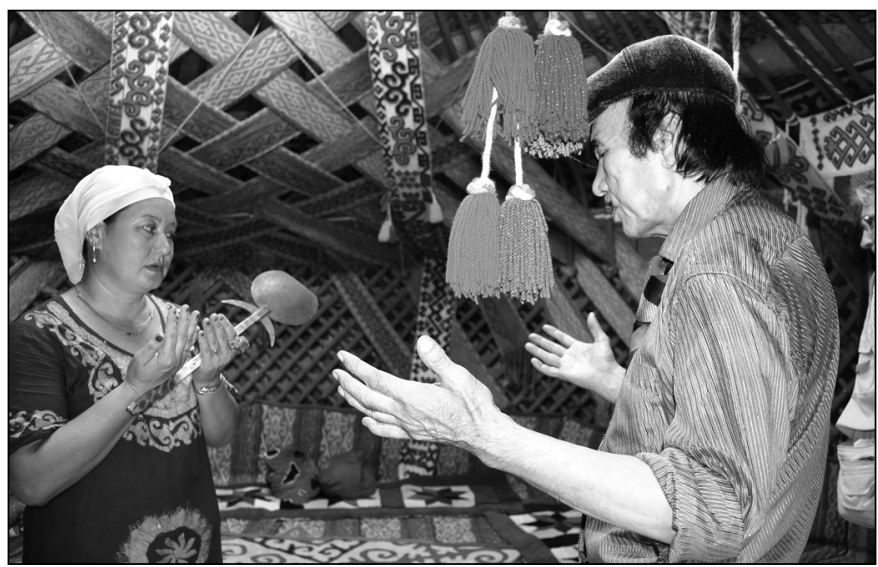

Figure 6. Bolatbek gives his blessing (bata) to his disciple who is praying with her magic shovel that she uses during the ritual after they heat it up by the fire, Aral Karakum, Kazakhstan, 2013. (Photo by Dávid Somfai Kara)

Kyrgyz have the Manas. For this reason epic tradition was never used by the state or by post-Soviet cultural movements to strengthen their national or ethnic identity. The epic cycle performed by Bolatbek actually has its roots in the Nogai Horde (1440-1634) whose eastern tribes later joined the Kazak Lesser Horde (Kishi Jüz).

Later his spirits also initiated him as a fortune-teller (köripker) and a spirit mediator (baksi). Today, Bolatbek no longer performs spirit-invoking rituals (zikir), and his epic storytelling is only requested by some repatriated Kazaks from Afghanistan. ${ }^{10}$ But during

${ }^{10}$ A sizable population of Kazaks (around 10,000) escaped to Iran and Afghanistan from the Soviet rule and the Great Famine (1932-33), when close to two million people died in the region. Half of the Kazaks in Iran and Afghanistan have returned to their homeland after 1992. 


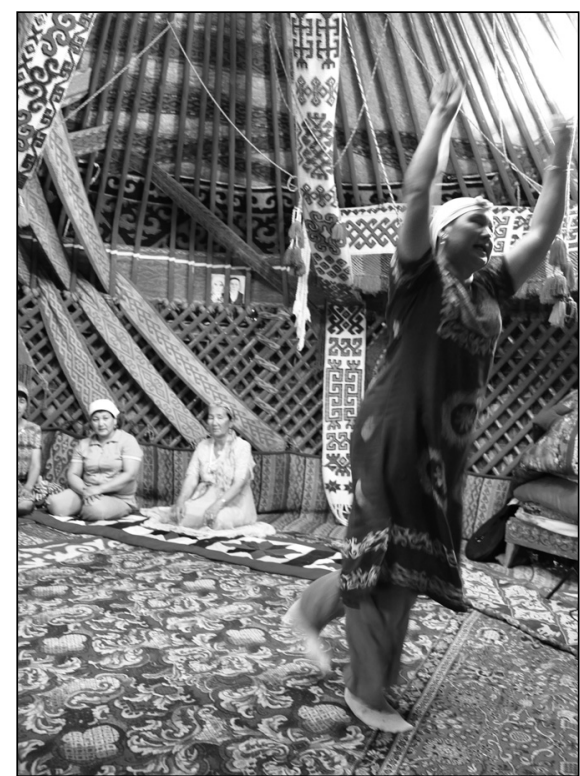

Figure 7. One of the disciples of Bolatbek performs the swan-dance during a spirit invoking ritual in a felt-house or yurta, Aral Karakum, Kazakhstan, 2013. (Photo by Dávid Somfai Kara)

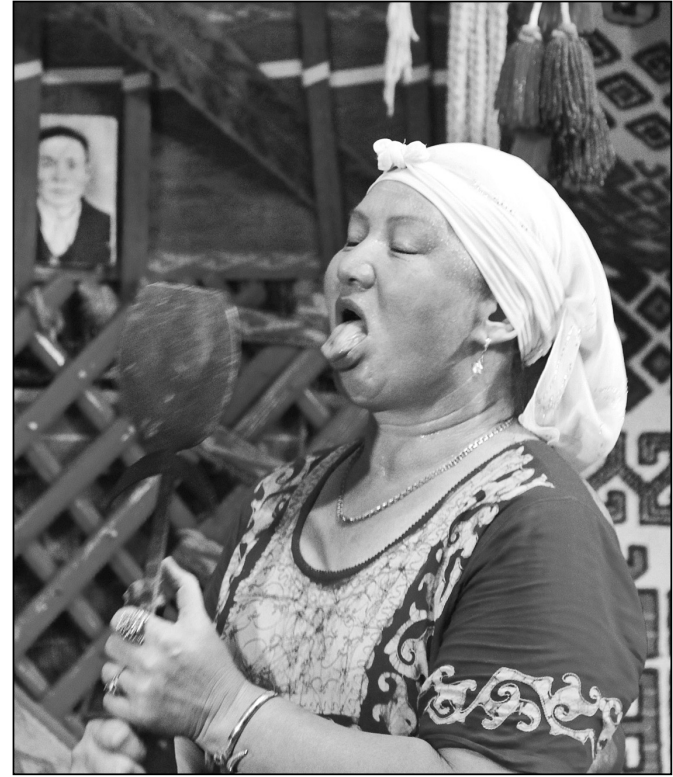

Figure 8 . The same disciple is licking a hot shovel to frighten the evil spirits (jïn) who cause illness and misfortune to the people, Aral Karakum, Kazakhstan, 2013. (Photo by Dávid Somfai Kara)

his active years he initiated four women, who were suffering from mental illnesses, to become spirit mediators. He also taught them how to perform rituals and the ritual dances. One of them was healing with a knife and another was even able to lick a hot shovel "to frighten the demons away," accompanied by a peculiar dance of the "swan spirit" (SomfaI 2010). ${ }^{11}$ These women started doing their activities on their own, but lately some of them are being prosecuted for illegal healing and witchcraft, due to the influence of the fundamentalist movement in the region by bribing the local officials to persecute traditional spirituality. When I attended their rituals, they were holding it secretly in a remote nomadic camp and asked me if I could get them international certificates to legalize their activities. Bolatbek sometimes still performs fortune-telling, even by communicating through his mobile phone. However, the tension was sensible around him due to the fundamentalist movement which he condemns. He accused one of his own sons who visited him during my stay that he had become a Wahhabi follower, which his son strongly denied.

\footnotetext{
${ }^{11}$ The Swan Spirit is a peri spirit that, according to some legends, turned into a woman and gave birth to the legendary forefather of the powerful Mangghit tribe who ruled the Nogai Horde (1440-1634) and Bukhara (1753-1920).
} 


\section{URBANIZED SPIRITUALITY}

Urbanized spirituality in post-Soviet times (Russian ektrosens) became really popular in the towns of the former Soviet republics, including Kyrgyzstan and Kazakhstan. Besides Russian and Oriental methods, this urbanized healing practice incorporated many local healing methods from folk medicine (GrzYwACZ 2010). But we have to be very careful when describing these healing methods; we cannot mix them up with the traditional religious beliefs and healing rituals. We should also avoid defining these healing methods as urbanized or neo-shamanistic. These urban healers often want to legitimize their healing activity by religious traditions and folk belief while they incorporate many foreign elements in their methods. Of course their activity also irritates the representatives of "official" Islam, who do not even try to differentiate urban esoteric healing from traditional folk medicine. Urban intelligentsia also has mixed feelings about these urbanized traditions. Most of them consider these folk healing methods merely as superstition (ï̈̈m).

At the same time, the Kyrgyz accept religious beliefs connected to Manas as part of their ethnic identity. Some of them accept that epic storytellers can be initiated by spirits but reject such initiation in the case of religious specialists or healers. The same opinion cannot be observed among the Kazaks, who lack the so-called "ethnic" epic tradition, and beliefs related to epic storytelling have also been forgotten. The urban intelligentsia with fundamental Muslim views rejects any kind of initiation by spirits.

\section{FUNDAMENTALIST ISLAM}

Muslim clerics educated in Arabic countries, often by fundamentalists such as the Wahhabi ${ }^{12}$ movement, do not tolerate Muslim folk traditions. Intolerance is stronger among the Muslims in big cities, who went through an acculturation and lost their contact with the values of rural societies, so they are completely indifferent towards them. Nowadays more and more conflicts occur because of the attack by Muslim circles against local religious traditions. Consequently, the rituals that have been practiced openly during the 1990s are now being held secretly to avoid the confrontation with the representatives of the "official" Islam, who are preaching against Muslim folk traditions in the mosques and trying to intimidate people from attending those rituals. Mosques are visited mostly by men, so Muslim folk rituals are attended predominantly by women. This gender issue increases religious tension within the families, too.

There are also examples of acceptance, however. In the sacred valley of Manjili-Ata by the Ysyk-köl, a mosque was built at the entrance of the valley by the local molla, who also respects the veneration of these sacred places (mazar). Of course, he urges people to say a prayer in the mosque before starting the pilgrimage in the valley, instead of taking part in rituals conducted by folk religious specialists. He tries to incorporate these

\footnotetext{
${ }^{12}$ The Wahhabi movement started in Saudi Arabia, founded by Muslim scholar Mohamed ibn Abdul-Wahhab (1703-1792). Wahhabi groups in Saudi Arabia give financial aid to many Muslim organizations in former Soviet countries, so they have a great influence in the region and among the religious leaders of Central Asia.
} 
traditions into "official" Islam, modernizing them instead of attacking openly. But this is a rare case, and the fundamentalist approach is becoming dominant not only in towns but in villages, too. The state avoids interfering with this conflict and sometimes supports the representatives of "official" Islam, although the political elite is mostly Russianorientated, received an atheist education, and they are also afraid of the increasing fundamentalism.

\section{GENERAL OBSERVATIONS}

In Central Asia the role of Islam was not as significant in nomadic societies as among settled people. Mosques and medrese-schools were built in the cities, not in the steppe or the mountains. Nomads rarely attended mosques, and their molla-teachers had less knowledge about the Qur'an and Sharia-law, so even molla-teachers believed in Muslim folk traditions and took part in them. Local Muslim traditions were simply called musulmancilik (BASILOV 1992:20) and they were an integral part of the Muslims' religious experience. The bakši specialists ${ }^{13}$ were initiated by the spirits (of Muslim saints, legendary heroes and chieftains) according to the will of Allah who granted them special abilities (hasiyat) to heal and divine. The chosen ones usually got ill in childhood and had visions ('ayan) in which spirits appeared to them and gave them food or drink. After consuming the food, their eyes "opened up to the spirit world" (Kyrgyz közü ačik). Similar initiation can be observed in the case of bards and epic storytellers based on the beliefs of popular Islam (SOMFAI 2003:189). Religious specialists played an important role in traditional societies. They did not only heal but also performed sacrifices, spirit invocations, divination and rain-magic. Their role was to communicate with the spirits (arwah) who protected the clan or the tribe and mediated towards Allah. They believed that God granted them those spirits and sacred places (mazar) to express his almighty power (Arabic qudrat). Interestingly, these folk religious traditions that sometimes incorporated pre-Islamic elements did not bother the Islamic clerics and they did not oppose them. Spirit-invoking rituals (dhikr and jahr, see SomFAI 2004:162; SOMFAI 2005:181-183) originate from Sufi rituals, and most helping spirits are also Sufi saints whose tombs are pilgrimage sites where some of the rituals take place.

Traditional and popular religious practices were based on Sufi traditions that partly originate from Central Asia. They also incorporated some pre-Islamic Turkic and Iranian elements. Rural communities consider these traditions an integral part of their Muslim identity (musulmančlik). During the Soviet times these traditions were prosecuted along other religious activities. Soviet ethnography wanted to prove that these ethnic traditions were the remnants of pre-Islamic "shamanism" in Muslim disguise, ignoring its 1000year history in Central Asia.

\footnotetext{
${ }^{13}$ The most widespread term for religious specialists in the eastern part of Central Asia (Kazak, Kyrgyz and Uyghur) is baksï/bakšï. The name comes from the Chinese bokshi, which originally meant some kind of teacher or doctor during the Buddhist Uyghur Era (856-1209). After the Islamization, religious specialists were named baksi//bakši in Eastern Turkestan. The bakši specialists practiced Sufi-type $z i k r$ rituals by invoking the spirits (arwāh) of Muslim saints (awliyā) and martyrs ( $\check{s} a h \bar{\imath} d)$. Nomadic people far away from Muslim religious centers practiced their faith through these bakši specialists. In the western part of Turkestan (Turkmen, Uzbek, Karakalpak), the name parihon/ porhan (ghost-caller) was more common for these specialists.
} 
The former ethnic approach of ethnology to the problem of popular Islam is also wrong because their traditions were more or less common to all the ethnic groups of Central Asia regardless of being nomadic or settled, linguistically Iranian or Turkic. In the post-Soviet era fundamentalist Islam earned influence among the Muslim leaders of Central Asia. They rejected local (folk) Muslim traditions, Sufism, and turned against these folk religious movements. So these traditions are now under greater threat than during the Soviet times when they were practiced secretly due to an external pressure. There is tension within the circles of these traditions, too; some specialists replace religious identity with ethnic identity. At the same time, urban esoteric healers and ethnically motivated "neo-pagan" movements are also incorporating elements of popular Islam into their practices, making the situation even more complicated.

\section{SUMMARY}

The study discusses Muslim traditions in Central Asia especially from the popular Islam among the Kazak and Kyrgyz and its conflict with modern (post-Soviet) religious movements such as Muslim fundamentalism, nationalism and neo-paganism. Muslim fundamentalism in Central Asia influences religious clerics who consider themselves representatives of "official" Islam while popular Muslim practices are labelled as shamanic remnants. These fundamentalists use the writings of Soviet scholars who tried to prove that Turks in Central Asia were not real Muslims and practiced the remnants of their pre-Islam shamanic tradition. However, these traditions have a long history and originate from Sufism or Muslim mysticism. Nationalist movements also incorporated some elements of popular Islam and tried to create some kind of ethnic religion, although these practices were regional and had nothing to do with ethnicity. At the same time neopagan and esoteric movements also use popular Islam to legitimize their activity which makes the situation even more complicated.

\section{REFERENCES CITED}

AYTPAEVA, Gülnara

2007 Mazar Worship in Kyrgyzstan. Rituals and Practitioners in Talas. Bishkek: Aigine Cultural Research Center.

BAsILOv, Vladimir

1992 Shamanstvo u narodov Srednei Azii i Kazakhstana [Shamanism among the Peoples of Central Asia and Kazakhstan]. Moskva: Nauka.

BaYAliEVA, Toktobübü

1972 Doislamskiie verovaniia $i$ ikh perezhitki u kirgizov [Pre-Islamic Beliefs and their Remnants among the Kyrgyz]. Bishkek (Frunze): Ilim.

BELLÉR-HANN, Ildikó

2004 Uyghur Healers (China). In Marico, N. Walter - Neumann Fridman, Eva Jane (eds) Shamanism. An Encyclopedia of World Beliefs, Practices, and Culture, 642-646. Santa Barbara, California: ABC Clio. 
DeWeEse, Devin

1994 Islamization and Native Religion in the Golden Horde (Baba Tükles and the Conversion to Islam in Historical and Epic Tradition). University Park: The Pennsylvania State University Press.

Divaev, Abubakr

1899 Iz oblasti kirgizskikh verovanii, Baksï kak lekar' i koldun (Etnograficheskii ocherk) [From the Field of Kirgiz Folk Belief, Baksï as Healer and Sorcerer]. Izvestiia Obshchestva arkheologii, istorii $i$ etnografii pri imperatorskom Kazanskom universitete 15(3):307-341.

GoLDEN, Peter B.

1992 An Introduction to the History of the Turkic Peoples. Wiesbaden: Harrassowitz. GRZYWACZ, ZuZanna

2010 Traditional Kazakh Medicine in Change. Poznań: Adam Mickiewicz University. (Turkic Studies 2.)

KeHL-Bodrogi, Krisztina

2006 The Reassertion of Religious Healing in Post-Soviet Uzbekistan. Asian Anthropology 5:111-129.

MÉLIKOFF, Irène

1989 Ahmed Yesevi and Turkic Popular Islam. Utrecht Papers on Central Asia 2:83-94.

SOMFAI KaRA, Dávid

2003 Living Epic Traditions among Inner Asian Nomads. In HoppáL, Mihály Kósa, Gábor (eds) Rediscovery of Shamanic Heritage, 179-194. Budapest: Akadémiai Kiadó.

2004 On a Rare Kyrgyz Ritual. Shaman 12:161-166.

2005 The Last Kazakh Baksi to Play the Kobïz. Shaman 13:181-187.

2006a A mongol és belsö-ázsiai török népi hitvilág szókincsének összehasonlitó nyelvi elemzése [A Comparative Linguistic Analysis of the Vocabulary Used to Express the Folk Beliefs of Mongolic and Turkic Peoples of Inner Asia], PhD dissertation. Budapest: ELTE BTK Nyelvtudományi Doktori Iskola.

2006b Batïkan, a Kazakh Shaman from the Altay Mountains (Mongolia). Shaman 14:117-138.

2007 The Sacred Valley of Jay Ata and a Kyrgyz Shaman from Xinjiang, China. Shaman 15:47-68.

2008a Mazars and Shamans. An Animist Concept of Worshipping Nature in the Popular Islam among the Kyrgyz. In HoPpáL, Mihály - SimONKAY, Zsuzsanna (eds): Shamans Unbound, 185-192. Budapest: Akadémiai Kiadó.

2008b An Uighur Baxši from the Ile Valley, Kazakhstan. Shaman 16:143-154.

2010 Baba Tükli and the Swan Girl. Legitimizing Elements in the Turkic Epic Edige. Acta Orientalia ASH 63:117-132. 
Dávid Somfai Kara is a Turkologist and Mongolist, a researcher at the Institute of Ethnology, Research Centre for the Humanities, Hungarian Academy of Sciences in Budapest. His PhD dissertation (2006) was on the vocabulary used to express the folk beliefs of Turkic and Mongolian peoples of Inner Asia. Between 1994 and 2016 he conducted fieldwork in Central Asia (Kazakhstan, Kyrgyzstan, Uzbekistan, Turkmenistan), Russia (Siberia, Ural, Caucasus), Mongolia and China (Xinjiang, Qinghai, Gansu, Inner Mongolia). He has collected oral literature (folksongs and epics) and data on Inner Asian folk beliefs among Kazak, Kyrgyz, Uygur, Bashkir, Nogay, Kumuk, Tuva, Altai Turks, Khakas, Sakha, Buryat, Daur, Khoton, Yugur and Salyr. Email-address: somfaikara@gmail.com 